\title{
Evidence for a Pythium sp. as a Chronic Yield Reducer in a Continuous Grain Sorghum Field
}

\author{
M. A. Davis, Associate Scientist, and W. W. Bockus, Professor, Department of Plant Pathology, Throckmorton \\ Plant Sciences Center, Kansas State University, Manhattan 66506-5502
}

\begin{abstract}
Davis, M. A., and Bockus, W. W. 2001. Evidence for a Pythium sp. as a chronic yield reducer in a continuous grain sorghum field. Plant Dis. 85:780-784.

Pythium spp. have been reported to reduce stands and cause stalk rot of grain sorghum. Evidence is presented that it also can cause a serious seed and root rot in the field under a continuous grain sorghum production system. Experiments were conducted for 4 years in a field that had been cropped continuously to grain sorghum for at least 10 years. Effects of seed treatments with captan and metalaxyl on plant stands, early to mid-season plant vigor, and grain yields were evaluated. In five field experiments, seed treatment with metalaxyl $(73 \mathrm{~g}$ a.i./100 kg) increased grain yields by an average of $24.0 \%$ compared with nontreated seed. In three out of four field experiments, seed treatment with metalaxyl increased grain yields by an average of $13.1 \%$ above seed treated with captan $(73 \mathrm{~g}$ a.i./100 kg). The yield increases could not always be explained in terms of differences among treatments in plant stands or in visual estimates of the amount of top growth 26 to 72 days after sowing. Apparently, the Pythium sp. causes a chronic root and seed rot that has a significant negative effect on grain production without necessarily affecting stands or early to mid-season growth. P. ultimum var. ultimum was the fungus most commonly isolated from roots and seeds collected from the field. Tests for Koch's postulates conducted in a greenhouse verified it as the causal organism. In the greenhouse, treatment with metalaxyl protected seeds and roots from attack by P. ultimum var. ultimum for at least 28 days after planting.
\end{abstract}

Species of Pythium can cause seedling diseases and root rots of many crops, including alfalfa $(1,20,22)$, corn $(4,25,26)$, cotton (3), sugarcane (19), and wheat (5$8)$. Seed treatment with the systemic oomycete fungicide metalaxyl (Apron) has reduced Pythium diseases on these crops $(3,6,20,30)$. Seedling diseases of grain sorghum (Sorghum bicolor (L.) Moench) also can be serious when cool, wet conditions occur after planting. Research has focused on the effects of Pythium spp. on sorghum seedling populations, early plant growth, resistance, lodging, and stalk rot $(2,3,12-16,23,24)$. Other stress factors, such as low or high soil $\mathrm{pH}$, herbicides, and herbicide antidotes, that delay the establishment of the permanent root system increase the potential of seedling root damage or damping off $(11,31)$. However, a chronic root rot of sorghum, caused by Pythium spp., and its effect on yield have not been documented.

Corresponding author: M. A. Davis

E-mail: Mdavis@plantpath.ksu.edu

This is contribution no. 01-134-J from the Kansas Agricultural Experiment Station.

Accepted for publication 19 March 2001.

Publication no. D-2001-0522-01R

(C) 2001 The American Phytopathological Society
In Kansas, there is a trend toward continuous sorghum production. Additionally, producers desire to plant early when soils typically are cooler and wetter. These practices may aggravate certain diseases, especially root rots. Metalaxyl is labeled for use on grain sorghum seed and has activity against Pythium root rot caused by various Pythium spp. This research was conducted to evaluate the effect of metalaxyl on plant stands, early to mid-season plant vigor, and grain yields of sorghum in a field that had been cropped continuously to grain sorghum for at least 10 years. Evidence is presented for the first time that $P$. ultimum var. ultimum causes a chronic root and seed rot of grain sorghum that negatively impacts grain yields in a continuous sorghum production system.

\section{MATERIALS AND METHODS}

Seven field experiments were conducted over a 4-year period (1994-96 and 1999) at the Kansas State University Rocky Ford Research Center located near Manhattan, KS. The soil type was a Chase silty clay loam and the field had been planted to grain sorghum in each of the previous 10 year. The field was moldboard plowed during the fall after harvest, then disked and harrowed in the spring just prior to planting. At 7 to 10 days before sowing, nitrogen, either as ammonium nitrate or urea, was incorporated by disking at 90 $\mathrm{kg} / \mathrm{ha}$. The experiment was arranged in a randomized complete block design with five replications. Plots consisted of two rows $0.75 \mathrm{~m}$ apart and either 6.1 or $9.1 \mathrm{~m}$ in length. Seed was sown with a cone-type planter with double-disk openers at rates to achieve a plant spacing of 7.5 to $10 \mathrm{~cm}$. The preemergence herbicide Propachlor + Atrazine 4F was applied to all plots at 4.5 $\mathrm{kg}$ in 190 liters of water per hectare with a backpack sprayer at $138 \mathrm{kPa}$. If rain did not occur within $48 \mathrm{~h}$, overhead sprinkler irrigation was used to incorporate the herbicide. During the season, visual plot vigor ratings were taken using a 1-to-5 scale, where 1 was a thin stand with small plants and 5 was a thick stand with large plants. Grain was harvested with a small-plot combine at maturity.

The fungicide seed treatment procedures were the same for field, greenhouse, and growth chamber experiments. Sorghum seed was nontreated or treated with metalaxyl (73 g a.i./100 kg; Apron-FL at $4.0 \mathrm{fl} \mathrm{oz} / \mathrm{cwt})$ or captan $(73 \mathrm{~g}$ a.i./100 kg; Captan 400D at $3.0 \mathrm{fl} \mathrm{oz} / \mathrm{cwt}$ ). Because the main goal of the experiments was to determine if sorghum responded to the use of seed treatments for control of oomycetetype fungi, a relatively high rate of metalaxyl was used to provide maximum protection. For treatment, a glass canning jar (1 liter) was "seasoned" by adding 2.5 $\mathrm{ml}$ of water, the correct amount of chemi$\mathrm{cal}$, and $100 \mathrm{~g}$ of seed and shaken until all liquid was absorbed by the seed. This seed was discarded, and the procedure was repeated to produce treated seed for the experiments. Treated seed was placed in paper bags to dry before sowing.

1994 field experiment. Planting occurred on 18 May using 1988 seed of the hybrid TX399 X TX430. Old, low-vigor (65\% germination) seed was chosen to maximize the potential for damping off. Eight seed treatments were used (9) but only nontreated and metalaxyl (73 g a.i./100 kg) are reported here because the other treatments did not have any effect on plant growth. Stand counts were taken on 31 May (13 days after sowing) by counting all emerged plants in the entire plot. Visual vigor ratings of each plot were taken on 29 July (boot stage, 72 days after sowing). Plots were harvested for grain on 3 November.

1995 field experiments. A repeat of the 1994 experiment was planted on 7 June (10). Germination of the old, low-vigor seed was $50 \%$. Stand counts were taken on 
23 June, vigor ratings were taken on 3 July (growing point differentiation), and grain yields were measured on 20 October. To determine if a high-vigor commercial hybrid (1994 seed with germination $>90 \%$ ) would respond to seed treatment control of oomycete fungi, and to determine if fungicide responses occurred with early and late planting dates, two additional field experiments were planted on 11 May and 7 June using Cargill 618Y. For these latter two experiments, seven treatments were included, but only nontreated, captan (73 g a.i./100 kg), and metalaxyl (73 g a.i./100 $\mathrm{kg}$ ) are presented here. Stand counts were taken on 12 and 23 Jun and vigor ratings were taken on 3 July at the boot and growing point differentiation growth stages. Grain yields were measured on 17 and 20 October.

Plant sampling. Plants from the 7 June planting date were sampled on 26 June to determine the presence of Pythium spp. on the roots. Five plants were dug from the terminal $1.0 \mathrm{~m}$ of each plot from nontreated seed. Roots were washed free of soil, cut into $1-\mathrm{cm}$ pieces, surface sterilized for $45 \mathrm{~s}$ in $0.5 \% \mathrm{NaOCl}$, and rinsed in sterile distilled water. Five randomly selected root segments per plant were plated onto an oomycete semiselective media containing corn meal agar (Difco Laboratories, Detroit) at $17 \mathrm{~g} /$ liter, ampicillin at $0.3 \mathrm{~g} / \mathrm{liter}$, and propiconazole at $50 \mu \mathrm{g}$ a.i./ml (=0.116 ml Tilt 3.6E/liter). Plates were incubated at room temperature for 24 to $48 \mathrm{~h}$ before examining root segments for Pythium colonies. Six randomly selected isolates were saved and later identified to species (29).

1996 field experiments. Repeats of the latter two 1995 experiments were planted on 2 May and 5 June 1996. Seed of the commercial hybrid Cargill 618Y (germination >90\%) from 1995 already had been treated with captan, so the two treatments used were captan (73 g a.i./100 kg) and captan plus metalaxyl $(73+73 \mathrm{~g}$ a.i./100 $\mathrm{kg})$. Plant stands were counted on 22 May and 21 June and vigor ratings were taken for both experiments on 3 July when growth stages were early flag leaf visible and growing point differentiation. Two additional isolates of Pythium were collected from the roots using the procedures described above and identified to species (29). Grain was harvested on 6 September and 16 October.

1999 field experiment. A field experiment was established on 11 May using 1998 seed of the commercial hybrid Alpha (germination $>90 \%$; Mycogen Seed, St. Paul, MN). Seed was not treated or treated with metalaxyl (73 g a.i./100 kg). Plant stands were counted on 25 May (14 days after sowing), visual vigor ratings of each plot were taken on 6 July (boot stage, 56 days after sowing), and grain yields were determined on 24 August.

Growth chamber and greenhouse experiments in naturally infested soil. Grain sorghum seed (Cargill 618 Y) was not treated or treated with captan or metalaxyl (both at $73 \mathrm{~g}$ a.i./100 kg). All growth chamber and greenhouse experiments were arranged in a randomized complete block design using 10 plastic tubes $2.5 \mathrm{~cm}$ in diameter by $15 \mathrm{~cm}$ long (Stuewe and Sons Inc., Corvallis, OR) per treatment per replication in four replications. Soil was collected from the experimental field site described above, and left nontreated or autoclaved at $121^{\circ} \mathrm{C}$ for $2 \mathrm{~h}$ and placed in the tubes. One seed was sown per tube and plants were maintained in a greenhouse at 15 to $27^{\circ} \mathrm{C}$ or a growth chamber at 10 to $15^{\circ} \mathrm{C}$ or 15 to $20^{\circ} \mathrm{C}(12-\mathrm{h}$ photoperiod). Plant counts and shoot fresh weights per plant were recorded after 28 days.

In other greenhouse experiments, using the same seed source and field soil, the effect of metalaxyl seed treatment on infection of roots and seeds by Pythium spp. was determined. Treatments included nontreated and metalaxyl-treated seed grown in tubes of autoclaved or nonautoclaved field soil. Five tubes were used per replication with one seed per tube in four replications. Tubes were incubated at 10 to $27^{\circ} \mathrm{C}$, and entire plants were collected after 10,14 , or 28 days of growth. Roots were washed free of soil, and root segments and seed coats were plated onto the oomyceteselective medium using the procedure described above.

Growth chamber experiments in artificially infested soil. Experiments to test Koch's postulates were performed with a single isolate of $P$. ultimum var. ultimum obtained from roots of grain sorghum from the area where field experiments were conducted. Experiments were conducted using Cargill 618Y and autoclaved soil from the same field. Treatments included nontreated, captan-treated (73 g a.i./100 $\mathrm{kg}$ ), or metalaxyl-treated (73 g a.i./100 kg) seed with or without Pythium inoculum. Inoculated treatments received four oat kernels infested with $P$. ultimum var. ultimum at seed level. Oat-kernel inoculum was prepared by placing $140 \mathrm{~g}$ of oat kernels overnight at $4^{\circ} \mathrm{C}$ in $150 \mathrm{ml}$ of distilled water in a 1-liter canning jar. Jars then were capped with a perforated, cottonplugged lid and autoclaved for $90 \mathrm{~min}$. When the oats had cooled, four or five agar plugs (8-mm diameter) from $P$. ultimum colonies were introduced aseptically into each jar, which was shaken to distribute the plugs. Jars were incubated at $24 \pm 3^{\circ} \mathrm{C}$ and shaken every 1 to 2 days for 7 to 10 days. Kernels were air-dried on a laboratory bench.

One sorghum seed was planted per tube with 10 tubes per replication in four replications per treatment. Two experiments were conducted in a growth chamber, one at 10 to $15^{\circ} \mathrm{C}$ and the other at 15 to $20^{\circ} \mathrm{C}$ (12-h photoperiod). Plant stands, shoot fresh weight per plant, and total shoot fresh weight were recorded after 28 days. To complete the test of Koch's postulates, isolations were made from roots as described above and colonies were compared with the original culture of $P$. ultimum var. ultimum. All growth chamber and greenhouse experiments were conducted at least twice with similar results.

Table 1. Effect of seed treatments (g a.i./100 kg) on stands, early to mid-season vigor, and yields of grain sorghum in the field ${ }^{\mathrm{w}}$

\begin{tabular}{|c|c|c|c|c|c|c|c|}
\hline Seed treatment & 1994 (18 May) & 1995 (7 Jun) & 1995 (11 May) & 1995 (7 Jun) & 1996 (2 May) & 1996 (5 Jun) & 1999 (11 May) \\
\hline \multicolumn{8}{|l|}{ Stands (plants $/ \mathrm{m})^{\mathrm{x}}$} \\
\hline Nontreated & $5.7 \mathrm{a}$ & $5.2 \mathrm{a}$ & $3.8 \mathrm{c}$ & $6.0 \mathrm{~b}$ & & & $3.5 \mathrm{~b}$ \\
\hline Captan (73) & $\ldots$ & $\ldots$ & $7.3 \mathrm{a}$ & $7.9 \mathrm{a}$ & $5.1 \mathrm{a}$ & $5.0 \mathrm{a}$ & .. \\
\hline Metalaxyl (73) & $5.9 \mathrm{a}$ & $4.8 \mathrm{a}$ & $6.3 \mathrm{~b}$ & $7.7 \mathrm{a}$ & $5.8 \mathrm{a}^{\mathrm{y}}$ & $5.8 \mathrm{a}^{\mathrm{y}}$ & $5.3 \mathrm{a}$ \\
\hline \multicolumn{8}{|c|}{ Vigor $(1 \text {-to-5 scale })^{\mathrm{z}}$} \\
\hline Nontreated & $4.0 \mathrm{a}$ & $3.4 \mathrm{a}$ & $2.3 \mathrm{~b}$ & $4.2 \mathrm{a}$ & $\ldots$ & $\ldots$ & $3.6 \mathrm{~b}$ \\
\hline Captan (73) & $\ldots$ & $\ldots$ & $2.9 \mathrm{a}$ & $4.0 \mathrm{a}$ & $4.2 \mathrm{a}$ & $4.0 \mathrm{a}$ & $\ldots$ \\
\hline Metalaxyl (73) & $4.0 \mathrm{a}$ & $3.8 \mathrm{a}$ & $3.1 \mathrm{a}$ & $3.6 \mathrm{a}$ & $4.2 \mathrm{a}^{\mathrm{y}}$ & $4.2 \mathrm{a}^{\mathrm{y}}$ & $4.3 \mathrm{a}$ \\
\hline \multicolumn{8}{|c|}{ Grain yields $(\mathrm{kg} / \mathrm{ha})$} \\
\hline Nontreated & $4,391 \mathrm{~b}$ & $5,341 \mathrm{~b}$ & $2,592 \mathrm{~b}$ & $5,651 \mathrm{~b}$ & & & $3264 \mathrm{~b}$ \\
\hline Captan (73) & & $\ldots$ & $2,754 \mathrm{~b}$ & $6,302 \mathrm{ab}$ & $7,027 \mathrm{~b}$ & $6,493 \mathrm{~b}$ & \\
\hline Metalaxyl (73) & $5,051 \mathrm{a}$ & $6,318 \mathrm{a}$ & 3,947 a & $6,742 \mathrm{a}$ & $7,641 \mathrm{a}^{\mathrm{y}}$ & $6,826 \mathrm{a}^{\mathrm{y}}$ & $4279 \mathrm{a}$ \\
\hline
\end{tabular}

${ }^{\mathrm{w}}$ Dates in parentheses $=$ planting date. Values within a column and parameter (stands, vigor, or yields) followed by a common letter are not significantly different according to analysis of variance followed by least significant difference $(P=0.05)$.

${ }^{x}$ Determined 13 to 20 days after planting.

y Metalaxyl (73) + Captan (73).

${ }^{\mathrm{z}}$ Determined 26 to 72 days after planting, with $1=$ thin stands, small plants and $5=$ thick stands, large plants. 


\section{RESULTS AND DISCUSSION}

Seed treatments with metalaxyl significantly $(P=0.05)$ increased stand counts compared with those from nontreated seed in three of five field experiments (Table 1). Captan also increased stands compared with nontreated seed in both experiments where nontreated and captan-treated seed were compared. In one of four experiments, treatment with captan resulted in higher stand counts than the treatment containing metalaxyl. The metalaxyl treatment also increased plant vigor ratings compared with those from nontreated seed in two of five experiments, whereas treatment with captan increased vigor ratings over those from nontreated seed in one of two experiments. However, vigor ratings of plants from captan- and metalaxyltreated seeds were not significantly different in any field experiment where they were compared.

Yield data from five field experiments indicated a significant yield increase when seed was treated with metalaxyl compared with nontreated seed (Table 1). Increases occurred whether old, low-vigor or new, high-vigor seed was used. Across all five experiments, the average yield increase was $24.0 \%$. Treatment with captan did not significantly affect yields in comparison to nontreated seed. However, the treatment containing metalaxyl increased yields over seed treated only with captan in three of four experiments. In this case, the yield increase averaged over all three experiments was $13.1 \%$.

Metalaxyl has activity only against oomycete fungi; therefore, our data provide indirect evidence that one or more oomycete fungi can cause substantial yield reductions of grain sorghum. Furthermore, yield increase even where stands were not significantly different between treatments (1994 and one experiment in 1995; Table 1). This suggests that stand differences alone could not account for the yield response. Similarly, treatment with metalaxyl increased yields even in experiments where vigor ratings were not significantly different from those of plants from nontreated seed (1994 and two experiments in 1995; Table 1). Additionally, metalaxyl produced a yield increase compared with captan in the metalaxyl seed treatment produced a

three of four experiments and, in all of those instances, there were no significant differences in vigor ratings. In fact, in one of the experiments (1995), captan resulted in more plants than metalaxyl and yet the reverse was true for grain yields, even though drought stress did not occur. Therefore, grain yield increases from metalaxyl occurred frequently even without obvious differences in plant stands or early to midseason growth.

A Pythium sp. was the only oomycete isolated from grain sorghum roots collected from the field. All eight isolates that were obtained over 2 years and identified to species (29) were P. ultimum var. ultimum. Although we only isolated one species of Pythium, other researchers have shown $P$. aphanidermatum (16), $P$. arrhenomanes (15), and P. graminicola (24) to be pathogenic on sorghum. Also, several species of Pythium have been reported to cause root rots on sugarcane (19), corn (26), and wheat (8). Therefore, additional Pythium spp. may be important in other production regions. The grain yield increases in our experiments occurred even in cases where there were no increases in plant stands or vigor ratings; therefore, $P$. ultimum var. ultimum likely is causing a chronic root rot that may go undetected unless a control treatment such as metalaxyl is used for comparison. Additionally, final stand counts are not as critical for grain sorghum as for other row crops in Kansas, such as corn (18) and soybeans (21), because of sorghum's ability to produce tillers. Grain sorghum that sustains early season stand reduction from abiotic factors (herbicides, adverse soil $\mathrm{pH}$ ) or from other seedling or seed diseases caused by Fusarium spp., can compensate during subsequent favorable environmental conditions by producing tillers, thus resulting in little or no reduction in grain production $(11,17)$. Therefore, we believe that the most important negative effect of attack by P. ultimum var. ultimum is the chronic root rot that it causes. Although there are reports of Pythium spp. causing stand reductions and stalk rots $(2,3,12-16)$, this is the first report of a chronic root rot of grain sorghum caused by $P$. ultimum var. ultimum.

Chronic root rot by Pythium spp. often did not cause sufficient damage to the plant

Table 2. Effect of soil sterilization and seed treatment $(\mathrm{g}$ a.i./100 kg) on stands (no./10) and fresh shoot weight ( $\mathrm{g} / \mathrm{plant}$ ) of grain sorghum in the greenhouse ${ }^{\mathrm{y}}$

\begin{tabular}{llccccc}
\hline & & \multicolumn{2}{c}{ Experiment 1 } & & \multicolumn{2}{c}{ Experiment 2 } \\
\cline { 3 - 4 } \cline { 5 - 6 } Seed treatment & Soil treatment & Stands & Fresh shoot wt & & Stands & Fresh shoot wt \\
\hline Nontreated & Autoclaved & $5.8 \mathrm{a}$ & $0.83 \mathrm{a}$ & & $7.8 \mathrm{a}$ & $1.03 \mathrm{a}$ \\
Captan (73) & Autoclaved & $7.5 \mathrm{a}$ & $0.85 \mathrm{a}$ & & $8.0 \mathrm{a}$ & $1.18 \mathrm{a}$ \\
Metalaxyl (73) & Autoclaved & $7.0 \mathrm{a}$ & $0.87 \mathrm{a}$ & & $8.0 \mathrm{a}$ & $1.15 \mathrm{a}$ \\
Nontreated & Nonautoclaved & $3.0 \mathrm{~b}$ & $0.57 \mathrm{~b}$ & & $5.5 \mathrm{~b}$ & $0.52 \mathrm{~b}$ \\
Captan (73) & Nonautoclaved & $7.0 \mathrm{a}$ & $0.60 \mathrm{~b}$ & & $7.8 \mathrm{a}$ & $0.69 \mathrm{~b}$ \\
Metalaxyl (73) & Nonautoclaved & $7.8 \mathrm{a}$ & $0.90 \mathrm{a}$ & & $8.0 \mathrm{a}$ & $1.07 \mathrm{a}$ \\
\hline
\end{tabular}

${ }^{y}$ Values within a column followed by a common letter are not significantly different according to analysis of variance followed by least significant difference $(P=0.05)$.

${ }^{\mathrm{z}}$ Soil from a field cropped continuously to grain sorghum with or without exposure to $121^{\circ} \mathrm{C}$ for $2 \mathrm{~h}$. to be detected during the vegetative growth phase. Sorghum growth is slow up to 25 $\mathrm{cm}$ in height, because most of the plant's resources are being used to develop a strong root system and accumulate plant nutrients (27). Although only 5\% of plant growth occurs in this period, the plant takes up 15 to $20 \%$ of the nutrients it will use during the entire season (28). This emphasizes the importance of a healthy root system early in the season. Any impairment of the root system by a chronic root rot would have negative effects on water transport, nutrient uptake, and ultimately yield.

In the greenhouse experiments, plants grown in autoclaved field soil had no differences in stands or fresh shoot weights among any of the seed treatments (Table 2). Conversely, captan- and metalaxyltreated seed produced significantly more plants than nontreated seed in the nonautoclaved field soil. There were no differences in stands between captan- and metalaxyltreated seed in the nonautoclaved soil treatment. However, treatment with metalaxyl increased fresh weights of seedlings over those from nontreated and captantreated seed in the nonautoclaved soil. Treatment with captan did not affect plant fresh weight when compared with nontreated seed. Therefore, bioassays in the greenhouse simulated what was observed in some of the field experiments. They also showed that metalaxyl was equivalent to autoclaving the soil for protecting plant stands and vegetative growth.

In the Koch's postulates experiment at relatively cool temperatures $\left(10\right.$ to $\left.15^{\circ} \mathrm{C}\right)$, plants failed to emerge from nontreated and captan-treated seed when inoculated with $P$. ultimum var. ultimum (Table 3 ). Plants did emerge from metalaxyl-treated seed, but were only $56 \%$ of the number from nontreated seed in noninfested soil. Nevertheless, the shoot fresh weights per plant and total shoot weights were not significantly different between the metalaxyl treatment and the noninoculated treatment, indicating effective control of Pythium root rot by metalaxyl. The other Koch's postulates experiment, conducted at warmer temperatures $\left(15\right.$ to $\left.20^{\circ} \mathrm{C}\right)$, also had severe stand reductions with the nontreated and captan-treated seed when inoculated with $P$. ultimum var. ultimum. Treatment with metalaxyl significantly increased plant numbers above those from nontreated and captan-treated seed. In fact, the number of plants in the metalaxyl treatment was not different from that in the noninoculated control. Metalaxyl also increased total shoot weights compared with those from nontreated and captan-treated seed. Results were comparable to those obtained in some of the field experiments. They showed that $P$. ultimum var. ultimum can reduce stands of grain sorghum and shoot weights but metalaxyl can effectively prevent those losses. Finally, the only 
pathogen isolated from diseased plants in all of these experiments was P. ultimum var. ultimum, and it appeared to be the same as the original culture.

The Koch's postulates experiments demonstrated that the disease was reproduced in the growth chamber. However, one difference between these experiments and those in the field was the apparent severity of the attack by $P$. ultimum var. ultimum. Increases in plant stands or vigor ratings with metalaxyl occurred in some of the field experiments but not in others. The experiments in the growth chamber simulated the former situation. The relative amount of inoculum or cool temperatures may account for the more severe disease produced in the growth chamber. In repeat experiments, damping off also was severe at cool temperatures $\left(10\right.$ to $\left.15^{\circ} \mathrm{C}\right)$ but less severe at warmer temperatures (20 to $25^{\circ} \mathrm{C}$; data not shown). However, additional research needs to be conducted to verify the effect of temperature on disease.

On wheat and barley, Pythium spp. primarily damage the fine rootlets $(5,7)$ and limit grain yields. A similar situation occurs on sorghum where treatment of seed with metalaxyl protected sorghum roots from infection by $P$. ultimum var. ultimum in all three experiments in the greenhouse (Table 4). It also protected seed from infection in both experiments where that parameter was measured. Metalaxyl protected roots and seeds for up to 28 days in experiment 3. Nevertheless, additional research needs to be conducted to determine the actual duration of protection.

This research supports the current widespread use of metalaxyl as a seed treatment on grain sorghum. In addition to protecting stands, it can significantly increase grain yields even where stand or growth reductions due to Pythium spp. are not visible. Protection from chronic root rot is as important as maintaining plant stands. In addition to protecting stands and root health, metalaxyl may enhance the natural resistance to internal spread of Pythium spp. (15) in some grain sorghum hybrids. Future research should focus on the identification, distribution, and prevalence of Pythium spp. causing a chronic root rot in continuous grain sorghum fields and the effect of crop rotation regimes on populations and disease severity.

\section{ACKNOWLEDGMENTS}

We thank L. E. Claflin and D. J. Jardine for their critical review of the manuscript.

\section{LITERATURE CITED}

1. Altier, N. A., and Thies, J. A. 1995. Identification of resistance to Pythium seedling diseases in alfalfa using a culture plate method. Plant Dis. 79:341-346.

2. Amador, J., Berry, R. W., Frederiksen, R. A., Horne, C. W., Thames, W. H., and Toler, R. W. 1970. Sorghum Diseases. Coop. Ext. Serv. Bull. B-1085. Texas A\&M University, College Station.

3. Botha, W. J., and McKenzie, D. 1993. Glasshouse evaluation of two metalaxyl formulations against cotton and grain sorghum seedling diseases caused by Pythium spp. Ann.
Appl. Biol. (Suppl.)122:34-35.

4. Callan N. W., Mathre, D. E., and Miller, J. B. 1990. Bio-priming seed treatment for biological control of Pythium ultimum preemergence damping-off in sh2 sweet corn. Plant Dis. 74:368-372.

5. Cook, R. J., and Haglund, W. A. 1982. Pythium Root Rot: A Barrier to Yield of Pacific Northwest Wheat. Agric. Res. Cent. Bull. XB0913. Washington State University, Pullman.

6. Cook, R. J., Sitton, J. W., and Waldher, J. T. 1980. Evidence for Pythium as a pathogen of direct-drilled wheat in the Pacific Northwest. Plant Dis. 64:102-103.

7. Cook R. J., and Tang, W. H. 1990. Influence of wheat chaff and tillage on Pythium populations in soil and Pythium damage to wheat. Soil Biol. Biochem. 7:939-947.

8. Cook, R. J., and Zhang, B. -X. 1985. Degrees of sensitivity to metalaxyl within the Pythium spp. pathogenic to wheat in the Pacific Northwest. Plant Dis. 69:686-688.

9. Davis, M. A., and Bockus, W. W. 1995. Influence of seed-treatment fungicides on stand establishment and yield of "old seed" grain sorghum, 1994. Fungic. Nematic. Tests 50:302.

10. Davis, M. A., and Bockus, W. W. 1996. Influence of seed-treatment fungicides on stand establishment and yield of "old seed" grain sorghum, 1995. Fungic. Nematic. Tests 51:297.

11. Davis, M. A., Jardine, D. J., and Todd, T. C. 1994. Selected pre-emergent herbicides and soil $\mathrm{pH}$ on seedling blight caused by Fusarium graminearum. J. Prod. Agric. 7:269-276.

12. Forbes, G. A. 1986. Pythium root rot. Pages 32-32 in: Compendium of Sorghum Diseases. R. A. Frederiksen, ed. American Phytopathological Society, St. Paul, MN.

13. Forbes, G. A., Collins, D. C., Odvody, G. N., and Frederiksen, R. A. 1985. A seedling epiphytotic of sorghum in South Texas caused by Pythium arrhenomanes. Plant Dis. 69:726.

Table 3. Effect of inoculation with Pythium ultimum var. ultimum and seed treatment ( $\mathrm{g}$ a.i./100 $\mathrm{kg}$ ) on growth of sorghum seedlings in sterilized field soil in a growth-chamberw

\begin{tabular}{|c|c|c|c|c|c|c|c|}
\hline \multirow[b]{2}{*}{ Seed treatment } & \multirow[b]{2}{*}{ P. ultimum $\mathrm{x}$} & \multicolumn{3}{|c|}{ Experiment 1} & \multicolumn{3}{|c|}{ Experiment 2} \\
\hline & & Stands & Fresh $^{y}$ & Total $^{\mathrm{z}}$ & Stands & Fresh & Total \\
\hline Nontreated & - & $9.0 \mathrm{a}$ & $0.6 \mathrm{ab}$ & $2.7 \mathrm{a}$ & $8.0 \mathrm{ab}$ & $1.8 \mathrm{a}$ & $14.3 \mathrm{a}$ \\
\hline Nontreated & + & $0.0 \mathrm{c}$ & $0.0 \mathrm{c}$ & $0.0 \mathrm{~b}$ & $3.5 \mathrm{c}$ & $1.1 \mathrm{bc}$ & $4.1 \mathrm{c}$ \\
\hline Captan (73) & - & $\ldots$ & $\ldots$ & & $7.3 \mathrm{~b}$ & $1.5 \mathrm{ab}$ & $10.7 \mathrm{~b}$ \\
\hline Captan (73) & + & $0.0 \mathrm{c}$ & $0.0 \mathrm{c}$ & $0.0 \mathrm{~b}$ & $4.0 \mathrm{c}$ & $0.9 \mathrm{c}$ & $3.6 \mathrm{c}$ \\
\hline Metalaxyl (73) & - & $\ldots$ & $\ldots$ & $\ldots$ & $9.3 \mathrm{a}$ & $1.5 \mathrm{ab}$ & $13.3 \mathrm{a}$ \\
\hline Metalaxyl (73) & + & $5.0 \mathrm{~b}$ & $0.8 \mathrm{a}$ & $2.0 \mathrm{a}$ & $7.8 \mathrm{~b}$ & $1.3 \mathrm{~b}$ & $10.0 \mathrm{~b}$ \\
\hline
\end{tabular}

${ }^{w}$ Soil was collected from a field that had been continuously cropped to grain sorghum and autoclaved $\left(121^{\circ} \mathrm{C}\right)$ for $2 \mathrm{~h}$. Soil was incubated at either 10 to

$15^{\circ} \mathrm{C}$ (experiment 1 ) or 15 to $20^{\circ} \mathrm{C}$ (experiment 2 ) in a growth chamber. Values within a column followed by a common letter are not significantly different according to analysis of variance $(P=0.05)$.

${ }^{x}$ Oat-kernel inoculum of $P$. ultimum var. ultimum added to the sterilized soil.

y Shoot fresh weight, grams per plant.

${ }^{\mathrm{z}}$ Total shoot weight in grams.

Table 4. Effect of seed treatments $(\mathrm{g}$ a.i./100 kg) on percentage sorghum seeds or root pieces colonized by Pythium spp. after growth in grain sorghum field soil in the greenhouse

\begin{tabular}{|c|c|c|c|c|c|c|c|c|}
\hline \multirow[b]{3}{*}{ Seed treatment } & \multirow[b]{3}{*}{ Soil treatment } & \multirow{3}{*}{$\begin{array}{c}\text { Experiment } 1 \\
10^{y} \\
\operatorname{Root}^{\mathrm{z}}\end{array}$} & \multirow{2}{*}{\multicolumn{2}{|c|}{$\frac{\text { Experiment } 2}{10^{y}}$}} & \multicolumn{4}{|c|}{ Experiment 3} \\
\hline & & & & & \multicolumn{2}{|c|}{$14^{y}$} & \multicolumn{2}{|c|}{$28^{y}$} \\
\hline & & & Root & Seed & Root & Seed & Root & Seed \\
\hline Nontreated & Autoclaved & $8.0 \mathrm{c}$ & $0.0 \mathrm{~b}$ & $0.0 \mathrm{~b}$ & $0.0 \mathrm{~b}$ & $0.0 \mathrm{~b}$ & $0.0 \mathrm{~b}$ & $0.0 \mathrm{~b}$ \\
\hline Nontreated & Nonautoclaved & $56.0 \mathrm{a}$ & $16.3 \mathrm{a}$ & $55.0 \mathrm{a}$ & $17.5 \mathrm{a}$ & $60.0 \mathrm{a}$ & $36.0 \mathrm{a}$ & $58.8 \mathrm{a}$ \\
\hline Metalaxyl (73) & Autoclaved & $6.0 \mathrm{c}$ & $0.0 \mathrm{~b}$ & $0.0 \mathrm{~b}$ & $0.0 \mathrm{~b}$ & $0.0 \mathrm{~b}$ & $0.0 \mathrm{~b}$ & $0.0 \mathrm{~b}$ \\
\hline Metalaxyl (73) & Nonautoclaved & $31.0 \mathrm{~b}$ & $0.0 \mathrm{~b}$ & $0.0 \mathrm{~b}$ & $0.0 \mathrm{~b}$ & $0.0 \mathrm{~b}$ & $2.0 \mathrm{~b}$ & $0.0 \mathrm{~b}$ \\
\hline
\end{tabular}

${ }^{x}$ Values within a column followed by a common letter are not significantly different according to analysis of variance followed by least significant difference $(P=0.05)$

y Days after sowing when plants were sampled.

${ }^{\mathrm{z}}$ Root $=$ mean of four replications with $25,1-\mathrm{cm}$ root segments per replication; and Seed $=$ mean of four replications with five or six seeds per replication. 
14. Forbes, G. A., Odvody, G. N., and Teri, J. M. 1986. Seedling diseases. Pages 7-8 in: Compendium of Sorghum Diseases. R. A. Frederiksen, ed. American Phytopathological Society, St. Paul, MN.

15. Forbes, G. A., Ziv, O., and Frederiksen, R. A. 1987. Resistance in sorghum to seedling disease caused by Pythium arrhenomanes. Plant Dis. 71:145-148.

16. Freeman, T. E., Luke, H. H., and Sechler, D. T. 1966. Pathogenicidty of Pythium aphanidermatum on grain crops in Florida. Plant Dis. Rep. 50:292-294.

17. Hickman, J. S., and Shroyer, J. P. 1988. Seedbed preparation and planting practices. Page 3 in: Grain Sorghum Production Handbook, C687. Coop. Ext. Serv. Kansas State University, Manhattan.

18. Hickman, J. S., and Shroyer, J. P. 1994. Optimum planting practices. Pages 8-11 in: Corn Production Handbook, C-560. Coop. Ext. Serv. Kansas State University, Manhattan.

19. Hoy, J. W., and Schneider, R. W. 1988. Role of Pythium in sugarcane stubble decline: Pathogenicity and virulence of Pythium species. Phytopathology 78:1688-1692.

20. Hwang, S. F. 1988. Effect of VA mycorrhizae and metalaxyl on growth of alfalfa seedlings in soils from fields with "alfalfa sickness" in Alberta. Plant Dis. 72:448-452.

21. Kok, H., Fjell, D. L., and Kilgore, G. L. 1997. Seedbed Preparation and Planting Practices, Pages 8-11 in: Soybean Production Handbook, C-449. Coop. Ext. Serv. Kansas State University, Manhattan.

22. Larkin, R. P., English, J. T., and Mihail, J. D. 1995. Effects of infection by Pythium spp. on the root system morphology of alfalfa seedlings. Phytopathology 85:430-435.

23. Odvody, G. N., and Forbes, G. 1984. Pythium root and seedling rots. Pages 31-35 in: Sorghum Root and Stalk Rots: A Critical Review. L. K. Mughogho, ed. International Crops Research Institute for the Semi-Arid Tropics, Patancheru, India.

24. Pratt, R. G., and Janke, G. D. 1980. Pathogenicity of three species of Pythium to seedlings and mature plants of grain sorghum. Phytopathology 70:766-771.

25. Rao, B., Schmitthenner, A. F., Caldwell, R., and Ellett, C. W. 1978. Prevalence and virulence of Pythium species associated with root rot of corn in poorly drain fields. Phytopathology 68:1557-1563.
26. Sumner, D. R., Gascho, G. J., Johnson, A. W Hook, J. E., and Threadgill, E. D. 1990. Root diseases, populations of soil fungi, and yield decline in continuous double-crop corn. Plant Dis. 74:704-710.

27. Vanderlip, R. L. 1972. Identifying stages of growth. Pages 5-6 in: How a Sorghum Plant Develops, C-447. Coop. Ext. Serv. Kansas State University, Manhattan.

28. Vanderlip, R. L. 1980. Understanding growth and development. Page 3 in: Grain Sorghum Handbook, C-494. Coop. Ext. Serv. Kansas State University, Manhattan.

29. Van der Platts-Niterink, A. J. 1981. Monograph of the genus Pythium. Stud. Mycol. 21:1-242.

30. Wilson D. O., Jr., Mohan, S. K., Knott, E. A. and Shafii, B. 1993. Evaluation of fungicide seed treatments for shrunken-2 ("supersweet") sweet corn. Plant Dis. 77:348-351.

31. Wright, D. L., Vanderlip, R. L., Regehr, D. L., Moshier, L. J., and Russ, O. G. 1992. Grain Sorghum Hybrid Response to Lasso and Dua Herbicides and Efficacy of Screen, Concept II, and Concept II/Apron Seed Safeners. Agric. Exp. Stn. Bull. 659. Kansas State University, Manhattan. 